\title{
Proteomic analysis of trochophore and veliger larvae development in the small abalone Haliotis diversicolor
}

\author{
Guilan Di ${ }^{1,2}$, Xianghui Kong ${ }^{1}$, Xiulian Miao ${ }^{3}$, Yifang Zhang ${ }^{2}$, Miaoqin Huang ${ }^{2}$, Yuting Gu², Weiwei You²*, \\ Jianxin Zhang ${ }^{1}$ and Caihuan $\mathrm{Ke}^{2^{*}}$
}

\begin{abstract}
Background: Haliotis diversicolor is commercially important species. The trochophore and veliger are distinct larval stages in gastropod development. Their development involves complex morphological and physiological changes. We studied protein changes during the embryonic development of $\mathrm{H}$. diversicolor using two dimensional electrophoresis (2-DE) and label-free methods, tandem mass spectrometry (MS/ MS), and Mascot for protein identification.

Results: A total of 150 2-DE gel spots were identified. Protein spots showed upregulation of 15 proteins and downregulation of 28 proteins as $\mathrm{H}$. diversicolor developed from trochophore to veliger larvae. Trochophore and veliger larvae were compared using a label-free quantitative proteomic approach. A total of 526 proteins were identified from both samples, and 104 proteins were differentially expressed (> 1.5 fold). Compared with trochophore larvae, veliger larvae had 55 proteins upregulated and 49 proteins downregulated. These differentially expressed proteins were involved in shell formation, energy metabolism, cellular and stress response processes, protein synthesis and folding, cell cycle, and cell fate determination. Compared with the 5 protein (fructosebisphosphate aldolase, 14-3-3ع, profilin, actin-depolymerizing factor (ADF)/cofilin) and calreticulin) expression patterns, the mRNA expression exhibited similar patterns except gene of fructose-bisphosphate aldolase.

Conclusion: Our results provide insight into novel aspects of protein function in shell formation, torsion, and nervous system development, and muscle system differentiation in H. diversicolor larvae. "Quality control" proteins were identified to be involved in abalone larval development.
\end{abstract}

Keywords: Haliotis Diversicolor, Embryonic development, 2-de, Label-free

\section{Background}

Some of gastropod larval development includes a pelagic phase (trochophore and veliger) and a benthonic phase. The trochophore and veliger are morphologically and behaviorally distinct developmental stages. Complex morphological and physiological processes occur during the transition between these stages. Morphological differences in the development of gastropod larvae have been reported [1-3]. Animal embryology research

\footnotetext{
* Correspondence: wwyou@xmu.edu.cn; chke@xmu.edu.cn

${ }^{2}$ State Key Laboratory of Marine Environmental Science, Fujian Collaborative

Innovation Center for Exploitation and Utilization of Marine Biological

Resources, Xiamen University, Xiamen, Fujian Province 361005, People's

Republic of China

Full list of author information is available at the end of the article
}

contributes to the development of the aquaculture industry and environmental pollution monitoring [4]. The embryonic development of gastropods includes several unique features including shell formation and head-foot differentiation [5]. Mollusk development involves shell formation or shell reduction, during which changes in body shape, deposition of minerals, and pigment deposition in a protein matrix occur [6]. The molecular mechanisms underlying these changes are unclear.

Abalones are marine gastropods distributed worldwide along coastal waters in tropical and temperate areas [7]. The small abalone Haliotis diversicolor (Mollusca, Gastropoda, Archaeogastropoda) is a commercially important 
species cultured along coastal waters [8]. In 2010, 50,000 tons of abalone were harvested in China [9].

Jackson et al. [1] observed significant differences in developmental events of the abalone Haliotis asinine. These included hatching from the vitelline envelope, variation in larval shell development, and metamorphosis-inducing cues in older larvae. While many proteins are involved in abalone shell formation, their presence and roles in early developmental stages of larval shell formation are not well understood [2,3]. Larval torsion of the shell is also important in the development of gastropods. The abalone trochophore and veliger larvae possess shell at the different stages of growth. Larvae hatch as trochophores, at approximately $19 \mathrm{~h}$ postfertilization (Fig. 1a), and the trochophore is the initial shell stage. The trochophore then undergoes a series of morphological changes, including velum acquisition, at which point it becomes a swimming larva in the pre-veliger phase (at $30 \mathrm{~h}$ ). The trochophore then transforms into a swimming veliger larva, and the late calcified protoconch forms (Fig. 1b). The veliger stage is characterized by differentiation of the larval retractor muscle, foot mass, mantle, and the onset of shell mineralization $[10,11]$.

Sequencing techniques, genomic data, and transcriptomic analysis have been used to study larval development, the transcriptome of the early life history stages of the California Sea Hare Aplysia californica has been reported [12]. However, current genomic data are insufficient to reveal the molecular mechanisms underlying the complex cellular processes of embryonic development [13]. The process by which shell matrix proteins are secreted and organized into larval shell architecture is largely unknown. Proteins determine phenotypes, which can be considered snapshots of genome expression [14]. Phenotypes are more complex than mere genomic expression, due to lack of a direct correlation between gene expression intensity and protein abundance, proteomic studies are powerful tools for the discovery of new proteins involved in developmental processes. Proteomic profiling has been applied to embryo studies of several invertebrates, including fruit flies (Drosophila melanogaster) [15], brine shrimps (Artemia franciscana) [16], honey bees (Apis mellifera) [17], fouling barnacles
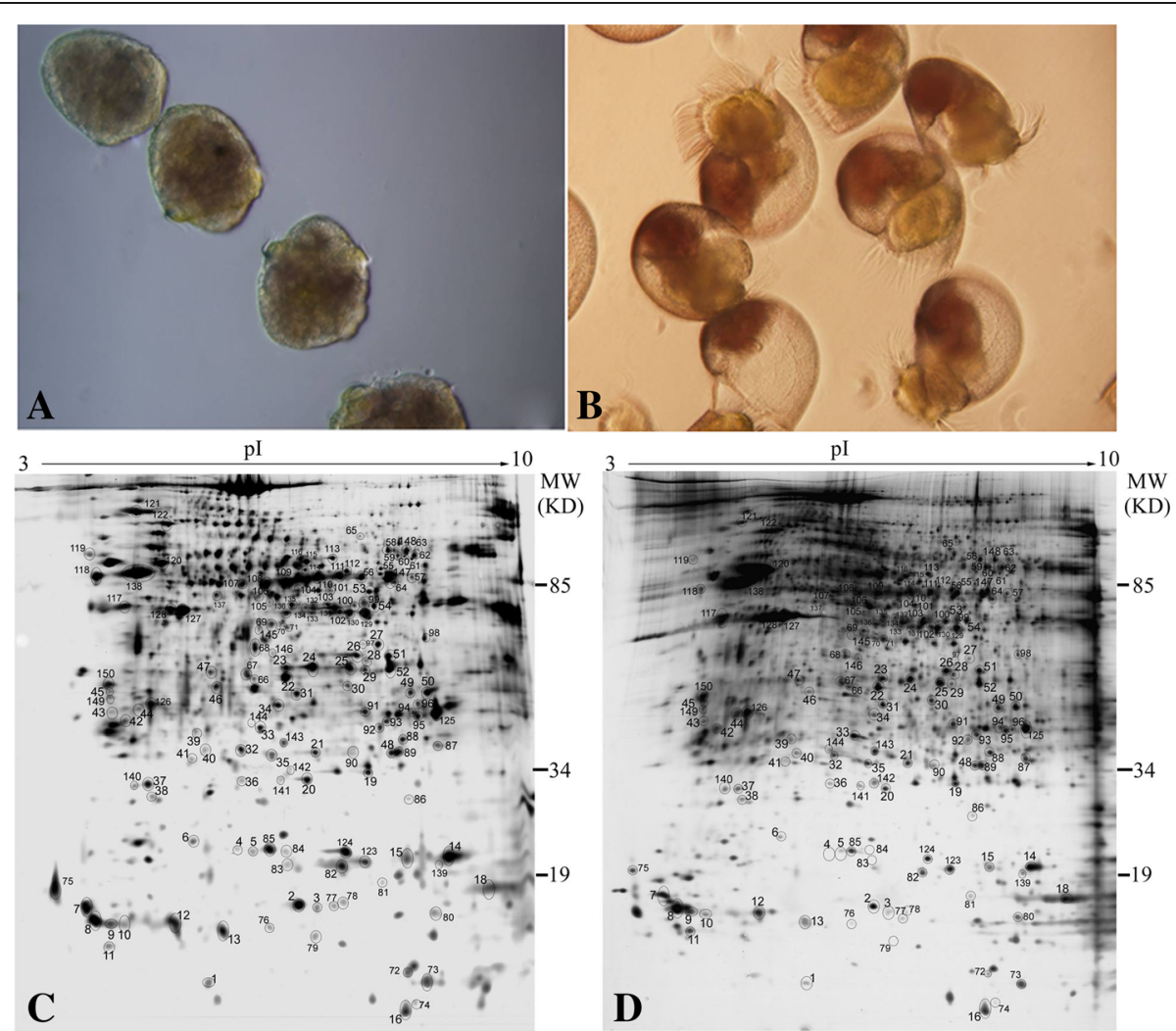

Fig. 1 Embryonic development of Haliotis diversicolor and 2-D gel images of silver-stained proteins $(120 \mu \mathrm{g})$. a a trochophore larvae stage, and (b) veliger larvae. Larvae hatch as trochophores at about $19 \mathrm{~h}$ post-fertilization. The trochophore larvae transform into swimming veliger larvae (at $30 \mathrm{~h}$ ). Images of 2-DE from (c) the trochophore larval proteins; (d) the veliger larval stage proteins. The spot-numbering scheme is based on the description in Additional file 2: Table S2 
(Balanus amphitrite) [18, 19], polychaetes (Pseudopolydora vexillosa) [20], ascidians (Ciona intestinalis) [21], golden apple snail (Pomacea canaliculata) [22], and Pacific oyster (Crassostrea gigas) [13].

Two-dimensional electrophoresis (2-DE) permits quantitative examination within a single gel electrophoresis experiment and it is a powerful tool for total protein separation. Matrix-assisted laser desorption/ionization (MALDI) mass spectrometry is a promising technique [23]. Label-free-based proteomics is broadly applied to biomarker discovery and proteomic profiling [24]. This technique is rapid, clean and simple. It can directly and precisely quantify protein expression without using labeling. Proteomic studies of abalone embryos have not been previous reported. To thoroughly evaluate larval proteome changes, we investigated the differential protein abundances during the different development stages of $H$. diversicolor using a label-free, coupled 2-DE proteomic approach. The results provide insights into the different protein groupings during shell formation and the differentiation of the larval retractor muscle, foot mass, and mantle.

\section{Methods}

Animals

Adult $H$. diversicolor were obtained from Dongshan Haitian Aquaculture in Fujian Province, China. Abalones were fed on red seaweed Gracilaria sp., and the water temperature was maintained at $26-28{ }^{\circ} \mathrm{C}$. Fertilized eggs were incubated for 19 and $38 \mathrm{~h}$ to allow development into trochophores and veligers, respectively. At each stage, almost all individuals were in the same phase of development as confirmed by microscopic examination. Fresh, living larvae, approximately $4000-5000$ per stage, were filtered on a $40 \mu \mathrm{m}$ filter and then collected in $1.5 \mathrm{~mL}$ tubes for further analysis. The trochophores (C1) $(0.192-0.216 \times 0.155-0.173 \mathrm{~mm})$ and veligers (C2) $(0.215-0.235 \times 0.170-0.185 \mathrm{~mm})$ were centrifuged for $3 \mathrm{~min}$ at $13,000 \times \mathrm{g}$. The larval material $(15 \mu \mathrm{L}$ of pellets $)$ was lysed in a $1.5 \mathrm{~mL}$ tube by using $1 \mathrm{~mL}$ of TRIzol and then stored at $-80^{\circ} \mathrm{C}$. The trochophore (or veliger) larval material was divided into three independent samples, and three technical replicates were performed for each sample to ensure reproducibility.

\section{Extraction of abalone proteins}

Protein extractions were performed using TRIzolmediated sample preparation as described previously [25]. The protein pellet was air-dried and resuspended in an isoelectric focusing (IEF) re-dissolving buffer (7 M urea, $2 \mathrm{M}$ thiourea, $4 \%[w / v]$ CHAPS, and $40 \mathrm{mM}$ Tris, $\mathrm{pH}$ 8.5). Protein concentration was measured using a Protein 2-D Quant kit (GE Healthcare). Samples were stored at $-70{ }^{\circ} \mathrm{C}$ prior to experiments.

\section{2-de}

A 2-DE was conducted as described previously [26]. Total protein $(120 \mu \mathrm{g})$ was used for each test. The first dimension (IEF) of gel electrophoresis was conducted on $18 \mathrm{~cm}$ immobilized $\mathrm{pH}$ gradient (IPG) strips using a nonlinear $\mathrm{pH}$ gradient ( $\mathrm{pH}$ 3-10, Amersham Pharmacia Biotech) with a horizontal electrophoresis apparatus (Bio-Rad). The sample, included in the rehydration solution was loaded on the IPG (Immobilized pH Gradient) strip holder. IPG dry strips were rehydrated with a rehydration buffer $(8 \mathrm{M}$ urea, $2 \%$ $(w / v)$ CHAPS, $20 \mathrm{mM}$ DTT, 0.5\% (v/v) IPG buffer 3-10, and $0.01 \%(\mathrm{w} / \mathrm{v})$ bromophenol blue, $\mathrm{pH} 7.4)$ at $50 \mathrm{~V}$. IEF was then initiated at $100 \mathrm{~V}$ for $2 \mathrm{~h}, 200 \mathrm{~V}$ for $2 \mathrm{~h}, 500 \mathrm{~V}$ for $1 \mathrm{~h}, 1000 \mathrm{~V}$ for $2 \mathrm{~h}, 4000 \mathrm{~V}$ for $2 \mathrm{~h}$, and finally $8000 \mathrm{~V}$ until $50,000 \mathrm{Vh}$. Before the second dimension, the IPG strips were soaked for $17 \mathrm{~min}$ in equilibration solution (6 M urea, $50 \mathrm{mM}$ Tris-HCI buffer, $\mathrm{pH} 8.8,30 \% \mathrm{v} / \mathrm{v}$ glycerol, $2 \%$ $\mathrm{w} / \mathrm{v}$ SDS, and a trace of bromophenol blue) containing $1 \% \mathrm{w} / \mathrm{v}$ DTT. Incubation was continued with equilibration solution containing $2.5 \%(\mathrm{w} / \mathrm{v})$ iodoacetamide for an additional $17 \mathrm{~min}$. The second dimension of gel electrophoresis was conducted on $12.5 \%$ polyacrylamide gels $(20 \mathrm{~cm} \times 20 \mathrm{~cm} \times 1.5 \mathrm{~mm})$ by using the protean Xi Cell (Bio-Rad). Equilibrated strips were placed onto gels to perform sodium dodecyl sulfate-polyacrylamide gel electrophoresis at $16{ }^{\circ} \mathrm{C}$. The separation was conducted at $12.5 \mathrm{~mA} /$ gel for $30 \mathrm{~min}$ and then $25 \mathrm{~mA} /$ gel for approximately $5.5 \mathrm{~h}$ until the dye front reached the gel bottom. The protein spots were visualized with silver nitrate.

\section{Image acquisition and analysis}

For each development period, three independent samples were used in 2-DE analysis, and three technical replicates were conducted for each sample. The 2-DE gels were scanned to create TIFF files using an image scanner (Amersham Biosciences, UTA-1100). Differences in spot intensity were analyzed with the PDQuest 8.0 software package (Bio-Rad) according to manufacturer instructions. All gels were matched with a selected reference gel. The following corrections were performed so that only true spots were identified. The background was subtracted and edited to correct possible errors by removing inaccurate spots. Spot intensities of stained gel images were quantified according to total spot density and normalized to total gel density using PDQuest. Spot intensity levels were normalized by expressing the intensity of each protein spot as a proportion of the total protein intensity in a gel (relative volume, \% vol). Only wellresolved spots were used; spots in overlapping areas, streaked areas, or near the edges were discarded.

\section{Statistical analysis}

Differences between the two larvae stage groups were compared using SPSS version 17.0 software. We tested 
the null hypothesis that the difference of spot amounts had a mean of zero. Spot analysis was performed using both qualitative and quantitative modes. Spot intensity analysis was performed using the two-sided Student's ttest. The $p$-value for each individual spot was adjusted to account for multiple testing using the false discovery rate (FDR) method [27]. A cutoff of 0.11 was used for the FDR to assess significance of results. This cutoff rate indicates that $11 \%$ of the spots with significant values are expected to be false positives [28]. An error probability of $\mathrm{q}<0.05$ was considered to be statistically significant. For quantitative analysis, only protein spots showing at least a 1.5-fold change among the three groups were compared in the PDQuest software and considered up-regulated or down-regulated in order to compensate for the technical variability between replicates. Protein spots detected quantitatively were compared between 'two groups'. For qualitative analysis, spots with at least 10-fold changes were considered absent/present [29].

\section{Mass spectrometric protein identification}

Protein identification was conducted as described previously [25]. Briefly, protein spots were excised from the 2-DE gel and digested with trypsin. The excised spots were washed for $10 \mathrm{~min}$ with water, then the spots were destained using $15 \mathrm{mM}$ potassium ferricyanide, $50 \mathrm{mM}$ sodium thiosulfate, and washed using $200 \mathrm{~L}$ Milli-Q $\mathrm{H}_{2} \mathrm{O}(5 \mathrm{~min} \times 3)$. Spots were then shaken in $200 \mu \mathrm{l}$ $200 \mathrm{mM} \mathrm{NH} \mathrm{HCO}_{3}$ solution for $20 \mathrm{~min}$, dehydrated using $200 \mu \mathrm{l}$ acetonitrile for $10 \mathrm{~min}$, and then the acetonitrile (ACN) was removed. The gel pieces (protein spots) were dried. Proteins were reduced by treatment with $10 \mathrm{mM}$ DTT for $30 \mathrm{~min}$ at $56{ }^{\circ} \mathrm{C}$, and alkylated with $55 \mathrm{mM}$ iodoacetamide. Trypsin digestion was performed by addition of $4 \mu \mathrm{l}$ of trypsin $(20 \mathrm{ng} / \mathrm{L})$ in $20 \mathrm{mM} \mathrm{NH} \mathrm{HCO}_{3}$ solution to each spot followed by incubation overnight at $37{ }^{\circ} \mathrm{C}$. The extract $(0.5 \mu \mathrm{L})$ was analyzed using MALDI/time-of-flight/time-of-flight (MALDI-TOF/TOF) with a 5800 Proteomics Analyzer (Applied Biosystems); the MALDI conditions were identical to those given in the literature [26]. The extracts were pooled, dried, and resuspended in the extracts using $5 \mu \mathrm{L}$ of $50 \%(\mathrm{v} / \mathrm{v}) \mathrm{ACN}$ and $0.1 \%(\mathrm{v} / \mathrm{v})$ trifluoroacetic acid (TFA). These liquids $(0.8 \mu \mathrm{L})$ were mixed with $0.3 \mu \mathrm{L}$ of matrix solution $(2 \mu \mathrm{g} / \mu \mathrm{L} \mathrm{R}$-cyano-4-hydroxycinnamic acid) in 50\% (v/v) ACN and 0.1\% (v/v) TFA. Proteins were identified from the peptide mass fingerprints obtained by MALDI-TOF/TOF. From the results of tandem mass spectrometry (MS/MS), up to 2000 laser shots were acquired, and peptides were fragmented with collision-induced decomposition at an energy of $1 \mathrm{kV}$. The 20 most intense precursors per spot were selected with a minimum signal-to-noise $(\mathrm{S} / \mathrm{N})$ ratio of 50 , and the peak detection criteria used a minimum $\mathrm{S} / \mathrm{N}$ of 10 .

\section{Mass spectrometric data analysis}

MS/MS peaks were retrieved using an in-house Mascot Distiller. Data files were screened against the protein database for identification with Mascot. A protein identification was accepted if it contained at least two identified peptides both having a minimal cutoff Mascot score of 24 . Peptides identified with a probability of $95 \%$ correct matches were considered as "significant sequences." Combined MS and MS/MS searches were conducted against the nrNCBI database. The search parameters were as follows: the enzyme was trypsin; the allowance was one missed cleavage site; the fixed modification was carbamidomethyl (cysteine); the variable modification was Met oxidation; monoisotopic mass values were obtained; protein mass was unrestricted; the peptide mass tolerance was $\pm 100 \mathrm{ppm}$; the fragment mass tolerance was $\pm 0.5 \mathrm{Da}$. Similarities were considered significant when the total ion C.I. \% was $\geq 95$, and the $\mathrm{E}$ value was below $\mathrm{e}^{-20}$. The decoy search was performed to estimate the false discovery rate (FDR).

The database used in this study was UniProtKB. The Gene Ontology (GO) database included vocabularies, contributed annotations, and provided full access to this information in several formats. GO and prediction subcellular localization were analyzed using http://www.uniprot.org/uniprot/. Predicted interactions of the identified differentially expressed proteins were made using the http://string.embl.de/ website.

\section{Filter-aided sample preparation protein digestion for label-free proteomic analysis}

The protein pellet was dissolved in a solution of urea $(6 \mathrm{M})$ and thiourea $(2 \mathrm{M})$. Proteins were reduced with dithiotreitol $(1 \mathrm{mM})$ for $30 \mathrm{~min}$, followed by alkylation with iodoacetamide $(55 \mathrm{mM})$ for $30 \mathrm{~min}$ in darkness. Incubation with trypsin (1 g/50 g protein) (Promega, Madison, WI) was conducted for $12 \mathrm{~h}$ at room temperature. The digestion was stopped by addition of $5 \%$ formic acid. The peptide mixture was desalted using reversed phase C18 Stage Tips (Thermo Fisher Scientific), then washed three times with $50 \% \mathrm{ACN}, 0.1 \%$ TFA; the peptide elutions were combined. Peptide concentration was determined using a NanoDrop spectrophotometer [30]. Peptides were frozen at $-70{ }^{\circ} \mathrm{C}$.

\section{Label-free liquid chromatography (LC)-MS/MS Q Exactive quantification}

The reversed-phase LC column was $5 \mu \mathrm{m}$, with $200 \AA$ pore size C18 resin (Hypersil Gold C18, Thermo Fisher Scientific, Bremen, Germany) in a $75 \mu \mathrm{m}$ i.d. $\times 10 \mathrm{~cm}$. After injecting the sample, the column was washed for 
5.5 min with $90 \%$ mobile phase A $(0.1 \%$ formic acid in water) and $10 \%$ mobile phase B $(0.1 \%$ formic acid in ACN). The peptides were eluted using a linear gradient of $10 \%-50 \%$ mobile phase B for $24 \mathrm{~min}$ and then $50 \%-$ $80 \%$ mobile phase B for 6 min at a flow rate of $300 \mathrm{~nL} /$ min, a column temperature of $30{ }^{\circ} \mathrm{C}$, and an injection volume of $10 \mu \mathrm{L}$. At least a $5 \mu \mathrm{g}$ sample of each digest was used, and each sample was analyzed three times.

Data-dependent label-free analysis was performed with three replicate injections of each sample using a Q Exactive mass spectrometer (Thermo Scientific) at a flow rate of $300 \mathrm{~nL} / \mathrm{min}$. The data-dependent program used for data acquisition consisted of a 70,000 resolution fullscan MS scan (AGC set to $10^{6}$ ions with a maximum fill time of $200 \mathrm{~ms}$ ), and the 10 most abundant peaks were selected for MS/MS using a 17,500 resolution scan (AGC set to $1 \times 10^{4}$ ions with a maximum fill time of $200 \mathrm{~ms}$ ) with an ion selection window of 1.6 mass-tocharge $(\mathrm{m} / \mathrm{z})$ ratio and a normalized collision energy of $30 \mathrm{eV}$. The under-fill ratio, which assigns the minimum percentage of the target value likely to be reached at maximum-fill time, was regarded as $0.1 \%$. The instrument was run with the peptide recognition mode enabled [31]. The program used a $40 \mathrm{~s}$ dynamic exclusion window to avoid repeated selection of peptides for MS/ MS. Survey scans were acquired at a resolution of 70,000 at $200 \mathrm{~m} / \mathrm{z}$, and resolution for HCD spectra was set to 17,500 at $200 \mathrm{~m} / \mathrm{z}$.

\section{Data analysis for label-free proteomic analysis}

Raw files were processed to peak lists. Raw spectra were converted to Mascot-generated files using Proteome Discoverer software (Thermo Scientific) and analyzed using SIEVE software, which quantified all detected peaks. The q-value was used to estimate false positive results. All data were obtained based on $99 \%$ confidence for protein identification by FDR $\leq 1 \%$. Statistical analysis was performed using a one-way ANOVA. $P$-values $\leq 0.05$ obtained by Tukey's test were considered significant. Protein abundances that changed less than 1.5 -fold were discarded [31].

We compared differentially expressed proteins in $\mathrm{C} 1$ and $\mathrm{C} 2$ with a correlation test using scatterplot. A heat map colour column was constructed based on the values of the differential proteins in two groups using HemI 1.0 statistical software.

\section{Experimental validation using RT-qPCR}

The differentially expressed protein genes were validated using RT-qPCR amplification to confirm the proteomic results. Quantitative real-time PCR was conducted using an ABI Quantstudio 6 Flex system with SYBR • Premix $\mathrm{Ex} \mathrm{Taq}^{\mathrm{Tm}}$ (TaKaRa, Japan) according to manufacturer instructions. Primer sequences were designed based on each identified gene sequence using Primer Premier 6 software (Premier Biosoft, USA) (Additional file 1: Table S1). PCR amplification experiments were conducted in triplicate under the following conditions: $95^{\circ} \mathrm{C}$ for $30 \mathrm{~s}$, then 40 cycles of $95{ }^{\circ} \mathrm{C}$ for $5 \mathrm{~s}, 55^{\circ} \mathrm{C}$ for $30 \mathrm{~s}$, and $72{ }^{\circ} \mathrm{C}$ for $30 \mathrm{~s}$. The results were normalized using 18sRNA and Y-box protein 1(GenBank accession no.JN997407.1) for each sample and the $2^{-\triangle \Delta C T}$ method. The expression levels of each gene in the two developmental stages were compared using a two-sided Student's t-test, and differences were considered statistically significant at $p<0.05$.

\section{Results}

\section{Identification of 2-DE spots}

Different proteins were separated by $2-\mathrm{DE}$, as shown in Fig. 1c-d. A total of 150 gel spots were identified. The identification results from MS/MS are summarized in Additional file 2: Table S2. The protein spots identified by MS/MS in the abalone larvae with normalized \% spot volumes calculated from the protein differential abundances, functions, and processes are summarized in Additional file 3: Table S3.

Among the differential abundance proteins identified, proteins from $15 \mathrm{GO}$ functional categories were upregulated and proteins from $28 \mathrm{GO}$ functional categories were downregulated between the protein samples from the trochophores and veligers (Fig. 2). The most of the upregulated proteins were involved in development (3 proteins including the 14-3-3 epsilon protein, 3monooxygenase/tryptophan5-monooxygenase activation protein, and the metal-dependent hydrolase [32-35]), stress response (3 proteins including the receptor of activated kinase $C$, glutathione-S-transferase isoform, and manganese-superoxide dismutase), ATP synthesis (3 proteins including GK21455, vacuolar proton-ATPase Esubunit, and ATP synthase F1), carbohydrate metabolism (2 proteins including SJCHGC09380 protein and citrate synthase 1 ), and transport (2 proteins including charged multivesicular body protein $4 \mathrm{c}$ and enoyl-CoA hydratase). Most downregulated proteins were involved in stress response ( 5 proteins including thioredoxin peroxidase 1 , thiol peroxiredoxin and $\mathrm{Cu}, \mathrm{Zn}$-superoxide dismutase), nucleic acid metabolism (4 proteins including dUTPase and inosine 5 '-phosphate dehydrogenase 1 ), cellular proliferation, development (2 proteins including actin depolymerisation factor/cofilin), calcium ion binding ( 2 proteins including calreticulin and calmodulin 2 ), transport (2 proteins including outer membrane protein A precursor and charged multivesicular body protein $4 \mathrm{c}$ ), iron storage (2 proteins including ferritin and soma ferritin), protein degradation (2 proteins including BRAFLDRAFT_260175 and ubiquitin carboxyl-terminal hydrolase 14), and transcription (2 proteins including 


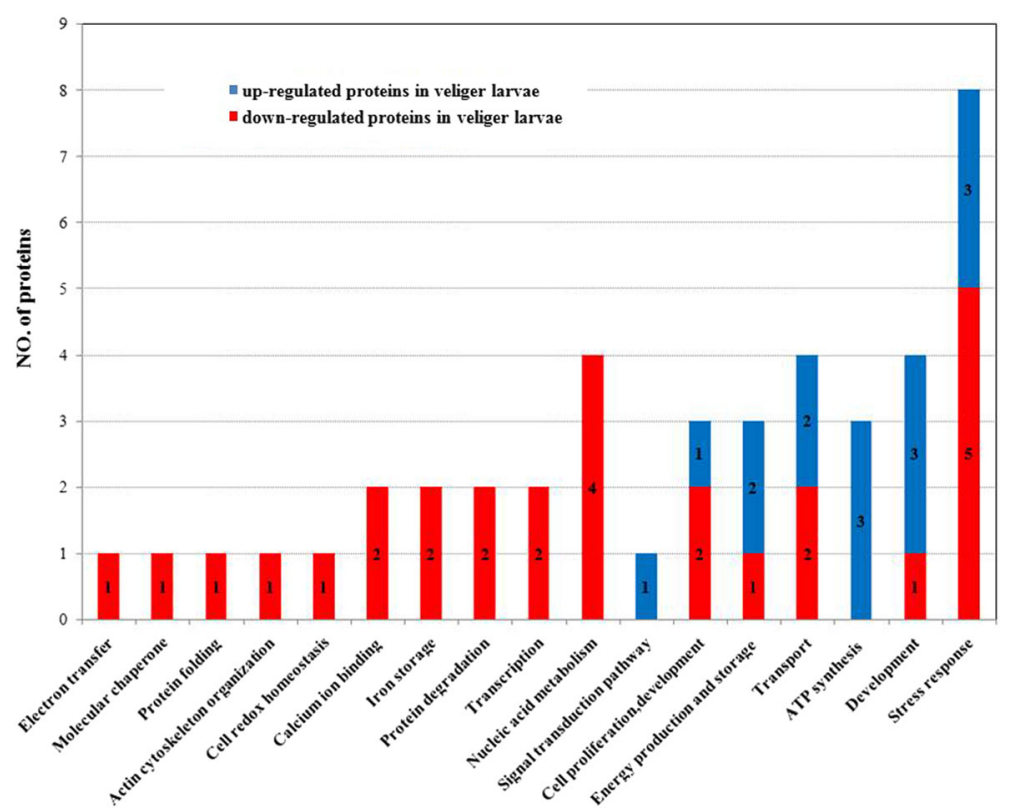

Fig. 2 The GO functional categories of the up-regulated or down-regulated differential abundances proteins based on 2-DE. Color codes are number of proteins identified by different analysis

similar to pterin-4a-carbinolamine and prevent-hostdeath family protein).

\section{Label-free proteomic analysis}

A total of 526 proteins (FDR $<1 \%$, at least two unique peptides) were identified from both of the samples, and 104 differential abundance proteins ( $>1.5$-fold) were detected using the label-free comparative proteomic approach. The veligers had 55 upregulated and 49 downregulated proteins compared with the trochophores (Additional file 4: Table S4). The upregulated proteins were involved in vitelline envelope zona pellucida, muscle contraction and regulation, translation, development, neurogenesis, nervous system development, stress response, and cell redox homeostasis (Fig. 3). The downregulated proteins were involved in muscle contraction and regulation, signal transduction, stress response, translation, and transport. As shown in Fig. 3, the

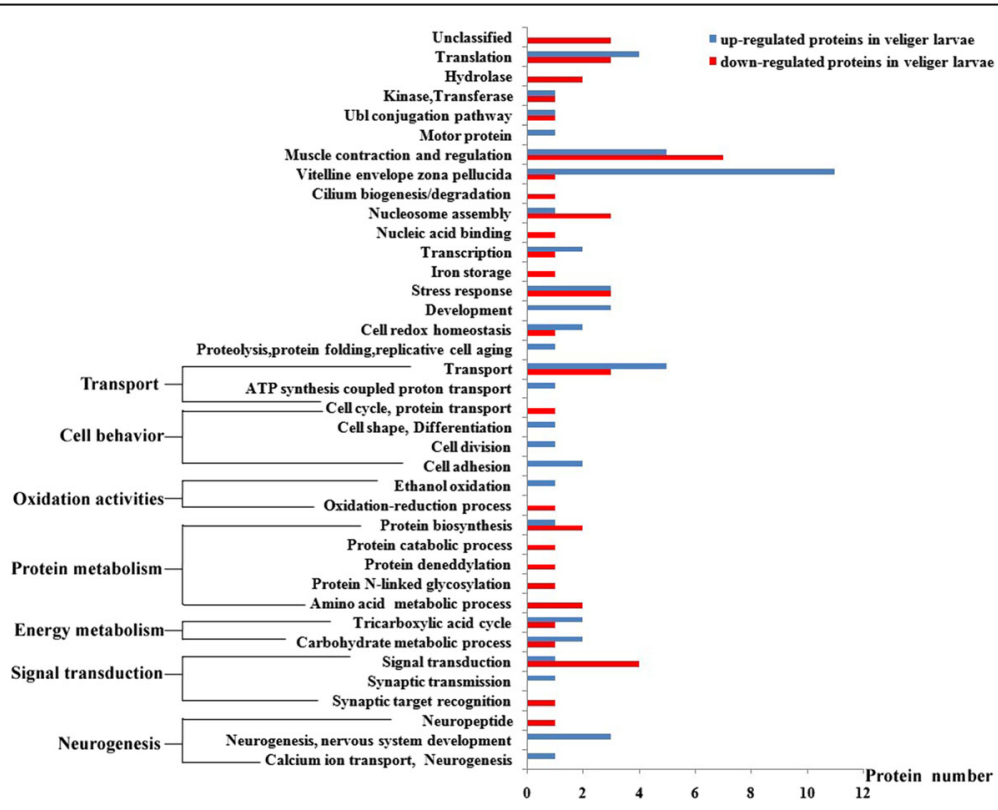

Fig. $3 \mathrm{GO}$ analysis for differentially abundant proteins of veliger larvae based on label-free analysis 
protein abundance profiles differed significantly in the trochophore and the veliger larval stages.

The boxplot shows information about the location and the spread of the data by means of the median and the interquartile range. To show the location and the spread of differentially expressed genes of different proteins in the two sample groups (trochophore and veliger larvae), we used a boxplot. A boxplot of read counts for each gene in the trochophore larvae $\left(\mathrm{C}_{1}\right)$ and veliger larvae $\left(C_{2}\right)$ is shown in Fig. 4a. The measurements for $C_{2}$ were more variable than $C_{1}$, but no significant differences were observed. Differentially expressed genes (red points) in the MA-plot (a graphical method for visualizing intensity-dependent ratio of raw microarray data) are shown in Fig. 4b.

To test whether there is a direct correlation in corresponding proteins, we compared the estimated concentrations of differentially expressed proteins in $C_{1}$ and $C_{2}$ with a correlation test (Fig. 5a). The correlation across the two stages was relatively low. Yet, decent positive correlation was still observed between $\mathrm{C}_{1}$ and $\mathrm{C}_{2}$, with a correlation score of 0.614 . To compare the abundance ranking of differentially proteins between $C_{1}$ and $C_{2}$, the abundance of 104 differentially proteins are showed in Fig. 5b. Among the top 31 most abundant proteins identified (Fig. 5c), 15 differentially expressed proteins increased over 5 fold in $\mathrm{C}_{2}$ and nine differentially expressed proteins decreased over 5 fold in $\mathrm{C}_{2}$.

\section{Comparisons of differential abundance proteins}

There were 142 nonredundant proteins with differential abundances between the trochophore and veliger larvae determined by both 2-DE and label-free LC-MS-based techniques. Of these, 38 and 99 proteins were exclusively identified and 5 proteins overlapped (Fig. 6a). In the veliger, $68(47.89 \%)$ proteins were upregulated and 74
(52.11\%) proteins were downregulated. The differentially expressed proteins were mainly related to transport (14), stress response (14), muscle contraction and regulation (13), protein metabolism (10), energy metabolism (9), signal transduction (8), and development (7) (Fig. 6 b).

\section{Prediction subcellular localization of protein}

The predicted subcellular locations of differentially expressed proteins are given in Fig. 7. The cellular components of 43 differentially expressed proteins in $C_{2}$ (by 2-DE gel analysis) are shown in Fig. 7a-b. The subcellular locations of upregulated proteins in $C_{2}$ were showed in Fig. 7 a, downregulated proteins in $\mathrm{C}_{2}$ were showed in Fig. 7 b.

Cellular components of 104 differentially expressed proteins in $\mathrm{C}_{2}$ (by label-free analysis) are shown in Fig. 7 c-d. Upregulated cellular components were showed in Fig. 7c, downregulated cellular component were showed in Fig. 7 d. A significant portion of the upregulated proteins in $\mathrm{C}_{2}$ was in the collagen trimer $(1.82 \%)$, dynein complex (1.82\%), lysosome (1.82\%), synapse (1.82\%), troponin complex (1.82\%), ubiquitin ligase complex $(1.82 \%)$. A significant portion of the downregulated proteins in $\mathrm{C}_{2}$ was in the cytoplasm, HULC complex, nuclear chromatin (2.04\%), extracellular space $(4.08 \%)$, proteasome (2.04\%), and proton-transporting ATP synthase complex (2.04).

\section{Predicted interactions of identified differential proteins from larvae}

Predicted interactions are shown in Fig. 8. The number of interactive networks of protein co-expression is shown in Fig. 9. The differentially expressed coexpression proteins mainly included tumor protein p53 (tp53); ribosomal protein L26 (rpl26); eukaryotic translation elongation factor 1 alpha 1, like 1 (eef1a1l1); ATP
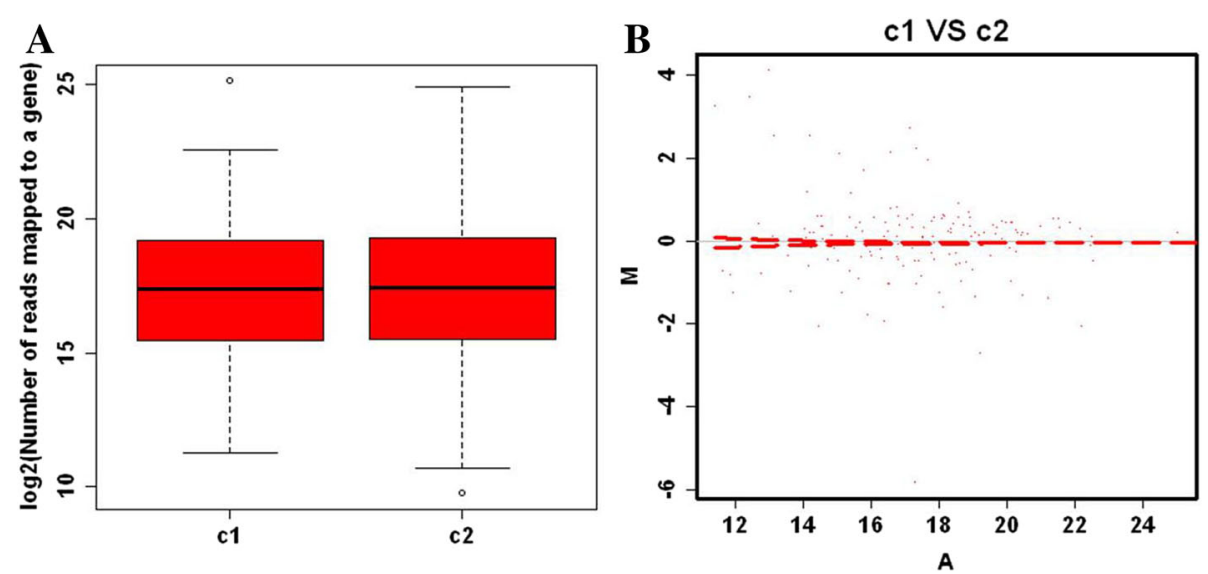

Fig. 4 Boxplot showing the location and the spread of differentially expressed genes of differentially abundant proteins. a Boxplot of read counts for each gene. $\mathbf{b}$ Differentially expressed genes on the MA-plot 


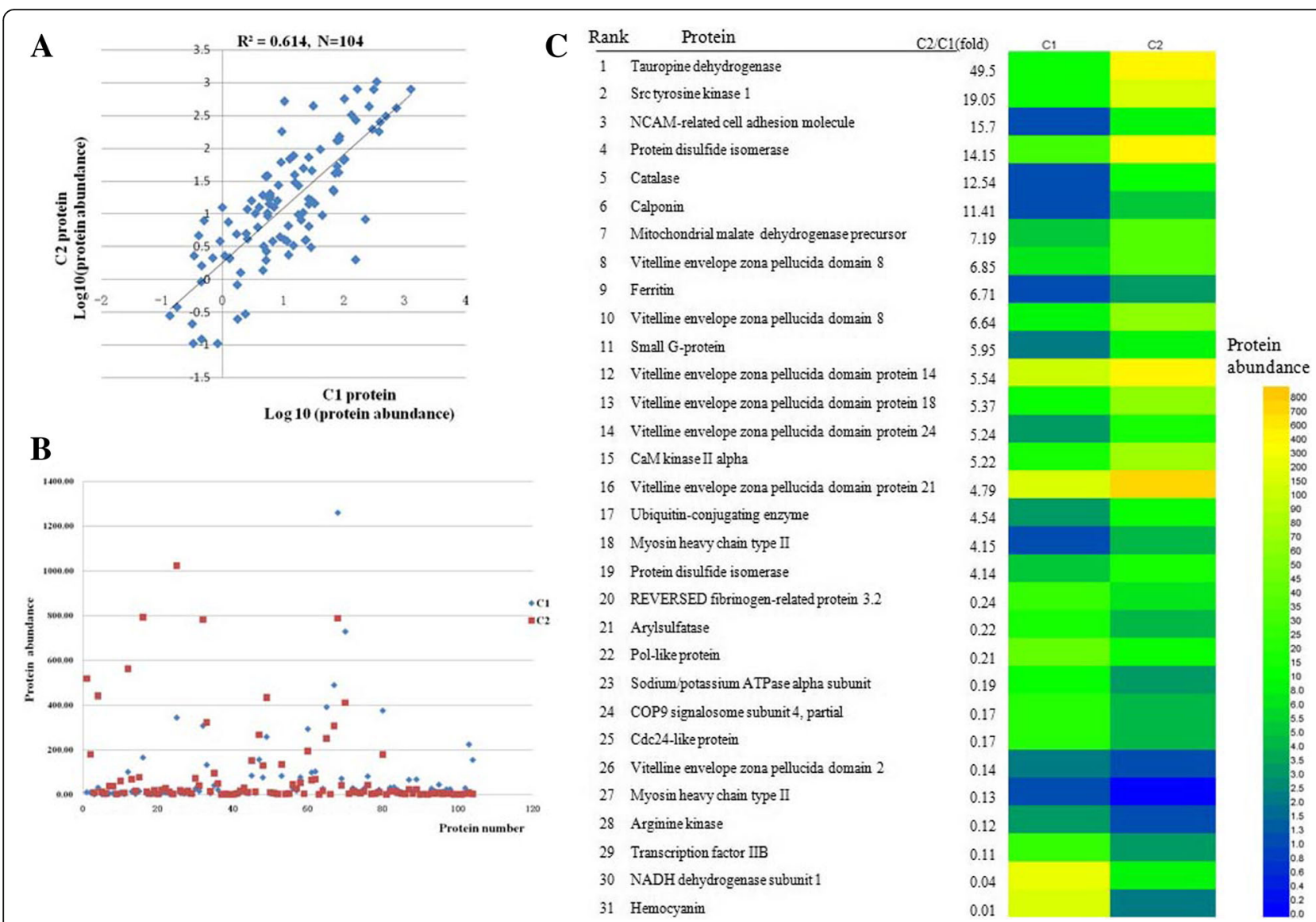

Fig. 5 Overlaps in ranks of proteins between C1 and C2. a Correlation between C1 and C2 proteins based on concentrations of 104 proteins; (b) The abundance of 104 differentially proteins; (c) Rank of top 31 abundant proteins

synthase, $\mathrm{H}+$ transporting, mitochondrial F1 complex, alpha subunit 1, cardiac muscle (atp5a1); ribosomal protein S9 (rps9); and ribosomal protein L10a (rpl10a).

\section{Comparison of protein expression and mRNA transcription}

To investigate the transcriptional levels of identified proteins, five of the ESTs matched by proteins $(\mathrm{AA}=$ fructose-bisphosphate aldolase, $\mathrm{BB}=14-3-3 \varepsilon, \mathrm{CC}=$ profilin, $\mathrm{DD}=$ actin-depolymerizing factor $(\mathrm{ADF}) /$ cofilin) and $\mathrm{EE}=$ calreticulin) were chosen for real-time PCR analysis. Melting curve analysis of the PCR products revealed only one melting temperature peak for each amplification reaction, ensuring the specificity of each primer pair. Compared with the protein expression patterns, the mRNA expression of four of the five genes (BB, CC, DD, and EE) exhibited similar patterns, while AA showed different variations (Fig. 10).

\section{Discussion}

Growth of abalone larvae in the trochophore and veliger stages involves many developmental events. However, the underlying molecular mechanisms of development remain largely unknown. The combined use of 2-DE and label-free quantitative proteomics method was adopted. Our combined proteomic approach suggests that novel aspects of the proteins identified are related to shell formation, torsion, nervous system development, and muscle systems.

In this study, only five proteins overlapped between the 2-DE and MS-based label-free results, that may have been caused as follows: Due to the inherent restrictions of 2-DE, the separation of proteins was limited by protein abundance, isoelectric point, molecular weight and hydrophobicity. It was difficult to effectively separate low abundance proteins with high molecular weight (molecular mass $>200 \mathrm{kD}$ ), low molecular weight (molecular weight $<8 \mathrm{kD}$ ) proteins, very basic proteins, and hydrophobic proteins. In addition, although there are more than 1000 protein spots on the 2-DE, the differential protein remains a concern, we only excised some of gel spots, many gel spots were not excised and identified. So, in this study, the number of identified proteins were limited by 2 -DE. On the other hand, the performance of the label-free proteomics method was restricted by limited abalone protein databases. It identified 


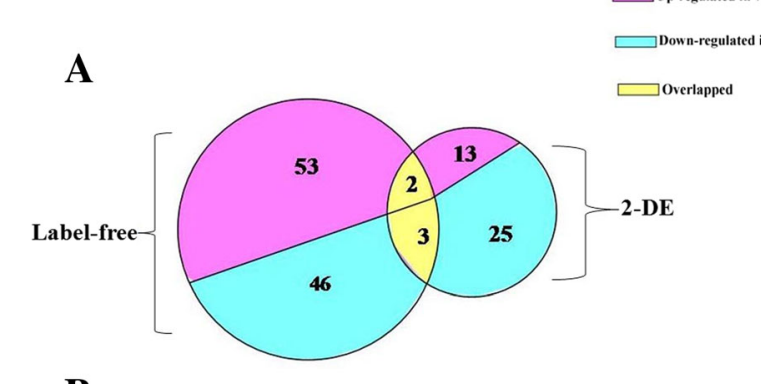

B

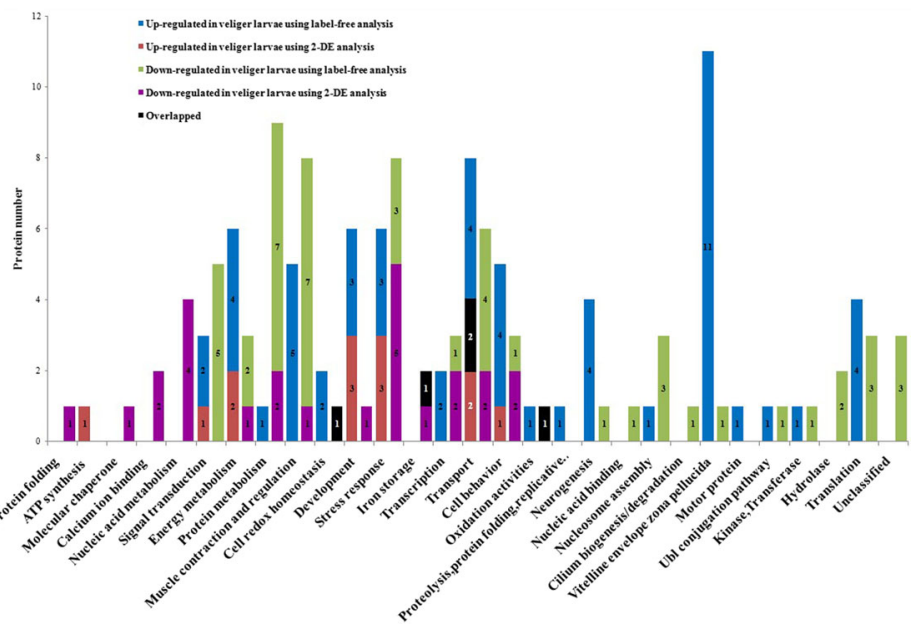

Fig. 6 Comparison of the differential proteins identified by 2-DE and label-free LC-MS analysis. a Venn diagram showing the distribution of 142 proteins. The large pie chart represents the proteins identified by the label-free LC-MS-based technique, and the small pie chart represents the proteins identified by the 2-DE technique. The numbers indicate the protein numbers in each partition. $\mathbf{b}$ Qualitative comparison of the protein numbers in veliger larvae. A total of 142 differentially abundant proteins are grouped into 29 categories according to their biological functions. Color codes are the protein numbers identified by differential analysis

hundreds of proteins but many proteins were not identified. There is relatively limited cDNA information available for abalone and possible improper annotations of abalone genes. Tryptic digestion resulted in acceptable MS/MS spectra with typical peptide signals, but these mass signals did not match any peptides available in the abalone protein databases. In previous studies, there were few overlaps between 2-DE and LC - MS based results [36].

\section{Proteins associated with Shell formation, torsion, and nervous system development}

Shell formation and changes in body shape are important components of abalone development. The 2-DE results showed that at least two proteins (calmodulin (spot 75) [37] and calreticulin (spot 118) [38]) upregulated in the trochophore stage are involved in molluscan shell formation. Calmodulin and calreticulin were also identified in the larvae of the snail $P$. canaliculata during shell development [22] and in the Pacific oyster C. gigas [13]. The upregulation of both proteins indicates that they may contribute to the calcification of larval shells. According to the label-free analysis, additional proteins
(CaM kinase II alpha, cadherin-like 3 protein, and calponin) involved in calcium ion transport and regulation were upregulated in the veliger stage. These proteins are likely involved in shell formation that occurs between trochophore and veliger larvae. In addition, calreticulin, as a protein-folding-related protein, can bind to misfolded proteins and either correct the protein folding or direct them toward a degradation pathway. Calreticulin constitutes a cellular protein "quality-control" system [39], that is very important for developmental processes.

In the label-free analysis, proteins 28,84 , and 87 were identified as $\mathrm{G}$ proteins. G proteins are important for larval metamorphosis of the abalone Haliotis rufescens [40]. Protein spots 126 and 150 were identified as 14-3$3 \varepsilon$ by 2 -DE gel analysis and 14-3-3 also plays an important role in left-right patterning during amphibian embryogenesis [41]. The 14-3-3 proteins are involved in neurodevelopment and $14-3-3 \varepsilon$ and $\zeta$ are associated with neurogenesis and neuronal progenitor cell differentiation in the developing brain [42]. Two spots identified as 14-3-3 increased in the veliger stage. Additionally, a real-time PCR assay also revealed upregulation of 14-3$3 \varepsilon$ mRNA expression in veliger larvae (Fig. 10 A 


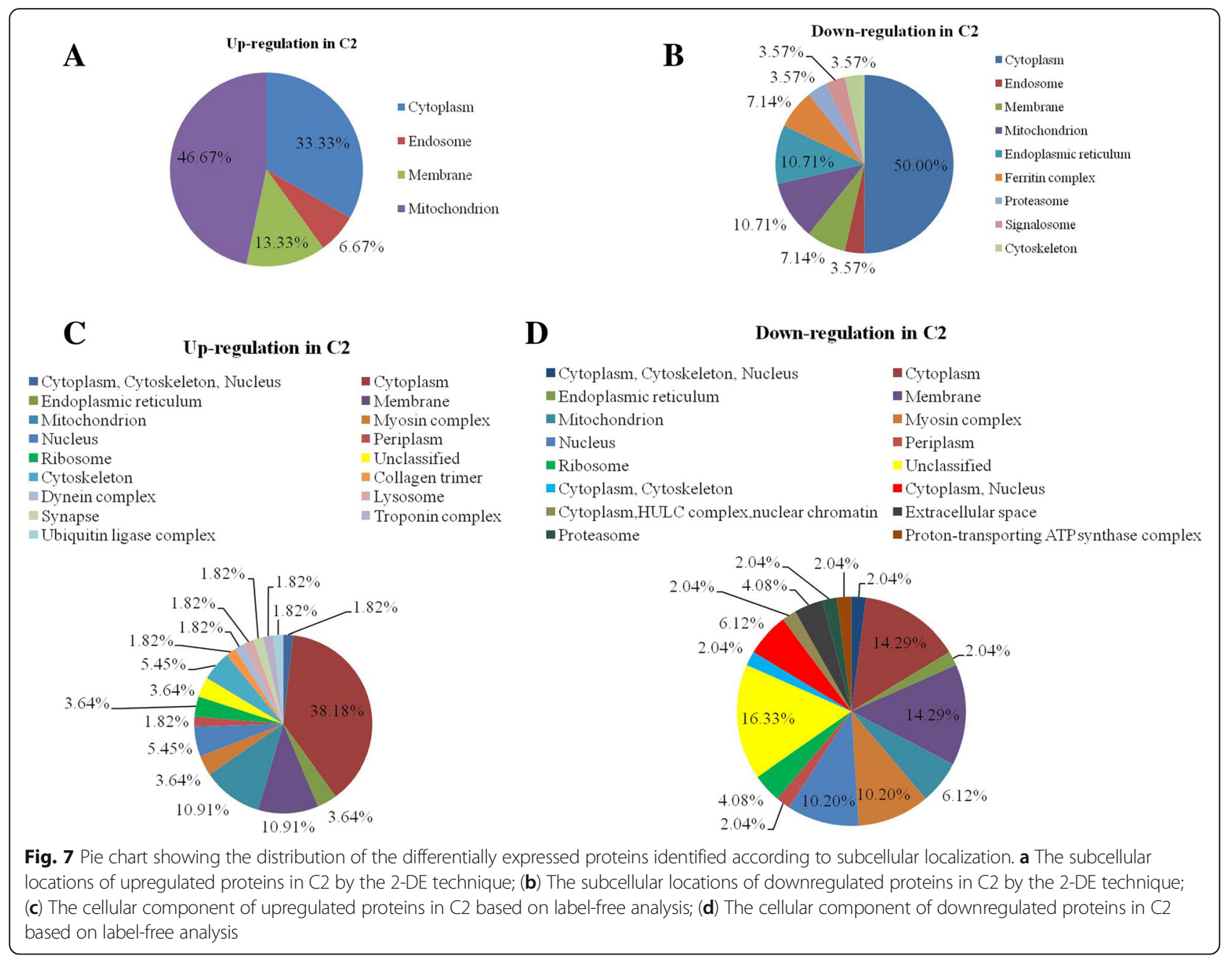

growing veliger undergoes a $180^{\circ}$ torsion that exerts a considerable effect on the morphology and anatomy of the adult mollusk form. The 14-3-3 may be related to the $180^{\circ}$ torsion and nervous system development of abalones.

Calmodulin and the 14-3-3 gamma protein play important roles in the nervous system, these two proteins are activators of tryptophan 5-monooxygenase and tyrosine 3-monooxygenase [13, 43, 44], which are importmant for the biosynthesis of serotonin, noradrenalin and adrenaline, which, as neurotransmitters, are crucial in neuronal activities [13, 32, 33]. The upregulation of the 14-3-3 protein and calmodulin in veligers might suggest their key roles in neuronal function and indicate an enhanced development of the nervous system as $H$. diversicolor transition from the trochophore to the veliger stage. This result is consistent with a study on the early larval development of the Pacific oyster C. gigas [13]. The nervous system development and regulation are not yet understood [13]. The identification of 14-3-3 and calmodulin proteins in our study suggests that the activation mechanism of tryptophan 5-monooxygenase and tyrosine 3-monooxygenase in $H$. diversicolor might be similar to that of mammals $[13,43,44]$. In the labelfree analysis, protein 6 was identified as a NCAMrelated cell adhesion molecule, which was up-regulated 15.7 fold in the veliger stage. The neural cell adhesion molecule (NCAM) plays a pivotal role in neural development, regeneration, synaptic plasticity, and memory processes [45].

In the 2-DE study, protein spots 1 and 3 were identified as ferritin. Ferritin is required for embryonic and larval development [46]. Ferritin is involved in neural development and is required multiple times during development [47]. Ferritin is also involved in shell formation [48]. The results of 2-DE analysis showed a high abundance of ferratin in trochophore larvae (protein spots 1 and 3). Label-free analysis identified protein number 16 as ferritin, which was downregulated in the veliger stage. Our results are consistent across both analyses. Ferritin is likely important for abalone embryo development. 


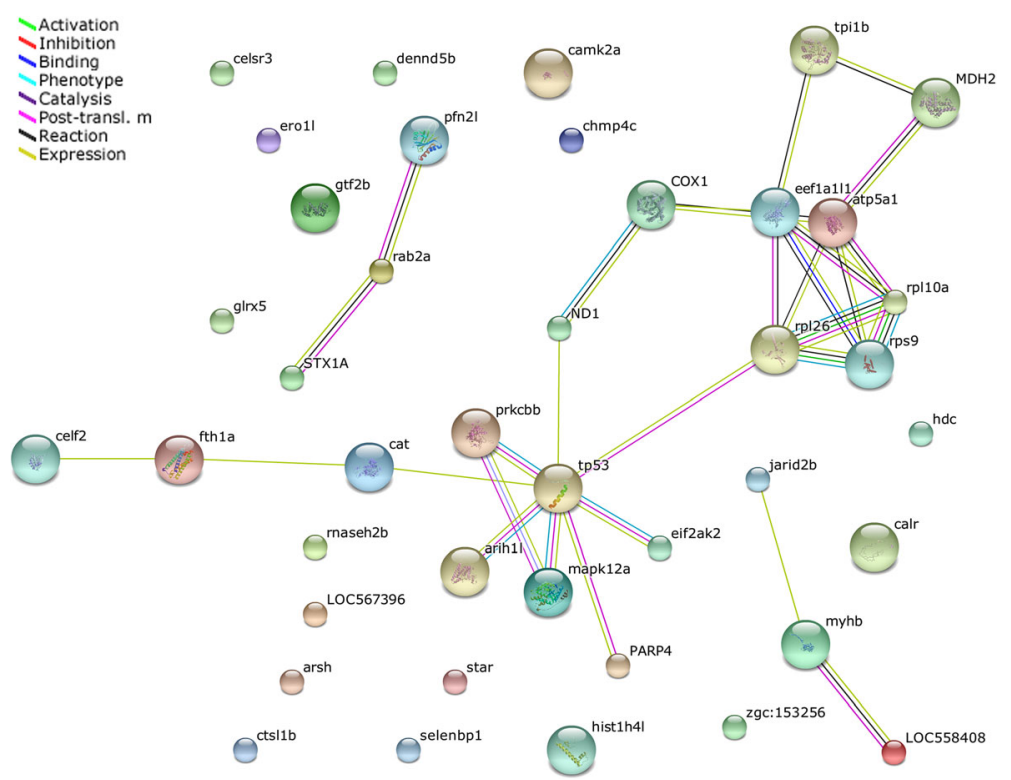

Fig. 8 Predicted interactions of identified differentially expressed proteins. Protein abbreviations and corresponding full name are shown: LOC558408 (troponin I); rab2a (RAB2A, member RAS oncogene family); myhb (myosin, heavy chain b); mapk12a (mitogen-activated protein kinase 12a); cat (catalase); fth1a (ferritin, heavy polypeptide 1a); atp5a1 (ATP synthase, H+ transporting, mitochondrial F1 complex, alpha subunit 1, cardiac muscle); prkcbb (protein kinase C, beta b); PARP4 [poly (ADP-ribose) polymerase family, member 4]; tp53 (tumor protein p53); arih1l (ariadne homolog, ubiquitin-conjugating enzyme E2 binding protein, 1 like); rpl26 (ribosomal protein L26); tpi $1 \mathrm{~b}$ (triosephosphate isomerase 1b); MDH2 [malate dehydrogenase 2, NAD (mitochondrial)]; ND1 (NADH dehydrogenase 1, mitochondrial); COX1 (cytochrome c oxidase l, mitochondrial)); eif2ak2 (eukaryotic translation initiation factor 2-alpha kinase 2); celf2 (cugbp, Elav-like family member 2); eef1a1l1 (eukaryotic translation elongation factor 1 alpha 1, like 1); pfn2l (profilin 2 like); jarid2b (jumonji, AT rich interactive domain 2b); STX1A [syntaxin 1A (brain)]; rps9 (ribosomal protein S9); rpl10a (ribosomal protein L10a)

\section{Proteins associated with muscle systems}

Larval retractor muscle appears encapsulated in the trochophore stage and enlarges as the organism enters the veliger stage. This muscle is required to retract the velum and head region into the protective larval shell in the veliger stage. The accessory larval retractor muscle and the velum ring muscle appear during the transition from the trochophore to the veliger stage [49]. Spots 5, and 123 were identified as members of the actindepolymerizing factor (ADF)/cofilin family by 2-DE analysis. ADF/cofilins depolymerize actin filaments and are essential regulators of actin dynamics. Muscular remodeling is essential for embryo development [50]. The abundance of ADF/cofilin family members was higher in the trochophore stage than in the veliger stage (spots 5 and 123).

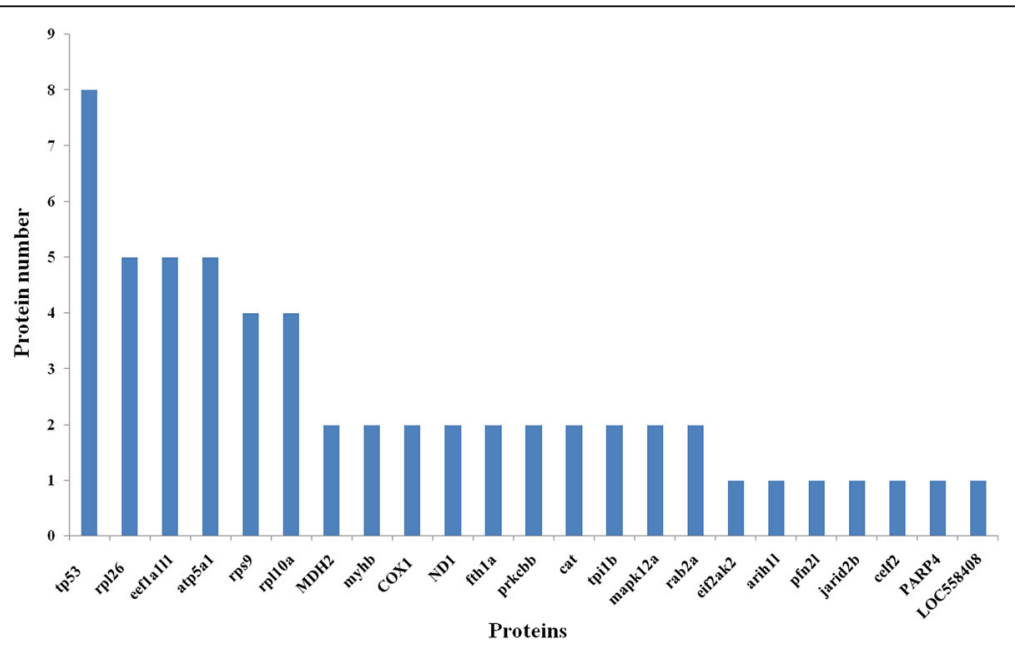

Fig. 9 Interactive network of protein co-expression 


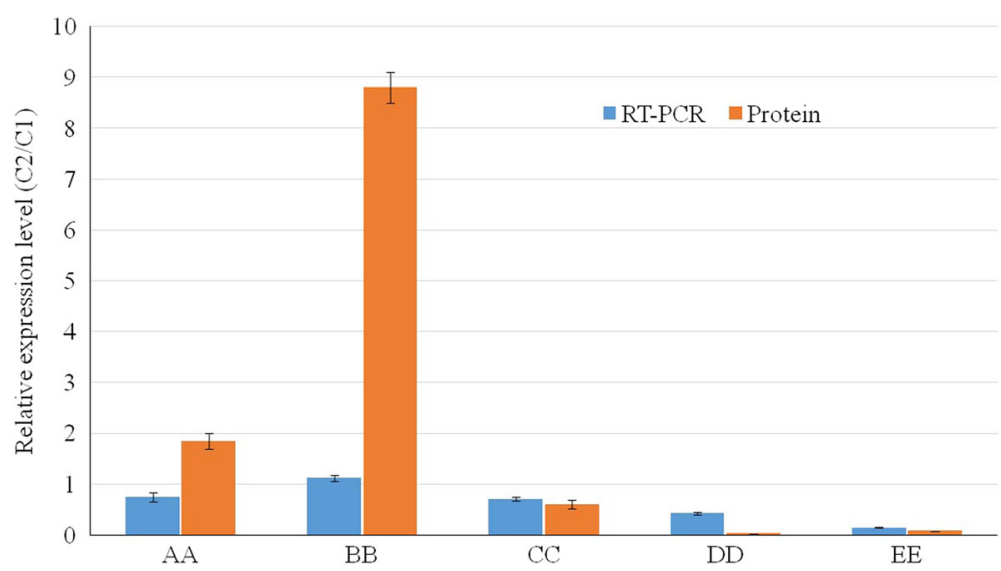

Fig. 10 Comparison of mRNA and protein expression levels for five genes in trochophore and veliger larvae. Values in each column represent the relative expression level of the mRNA or protein. Values greater than 1 represent up-regulations in veliger larvae, and values less than one indicate down-regulations. Four of the genes exhibited the same trend, but a discrepancy was observed between the mRNA expression and the protein level of the AA gene. $A A=$ Fructose-bisphosphate aldolase; $B B=14-3-3 \varepsilon ; C C=$ Profiling; $D D=$ Actin-depolymerizing factor $(\mathrm{ADF}) /$ cofilin; $\mathrm{EE}=$ Calreticulin

In the 2-DE study, protein spot 139 was identified as profilin, which is important for actin filament recycling and cell migration during development [51]. Profilins regulate actin polymerization [52] and can bind to formin proteins, stimulating the rapid addition of actin monomers to the pointed ends of actin filaments [53]. Profilin1 abundance was 15.82 in the trochophore stage and 9.56 in the veliger stage.

In the label-free analysis, protein 20 was identified as calponin, which was up-regulated 11.41 fold in the veliger stage. Calponin 3 participates in actin cytoskeleton-based activities in embryonic development and myogenesis [54].

\section{Proteins associated with other biological process of embryonic development}

Carbohydrates and lipids provide energy and nutrients for embryonic development [55]. We identified several proteins involved in energy metabolism (Additional file 3: Table S3). Glycolysis-related proteins play a key role in the embryonic development of zebrafish and ascidians [21]. In the label-free analysis, most proteins involved in carbohydrate metabolic processes were up-regulated in veliger larvae, including tauropine dehydrogenase, fructose-bisphosphate aldolase, and a mitochondrial malate dehydrogenase precursor. Among the top 31 most abundant proteins identified (Fig. 5c), tauropine dehydrogenase was up-regulated 49.5 fold in the veliger stage. We also noticed a discrepancy between the protein level and the mRNA expression of the fructosebisphosphate aldolase gene (Fig. 10 Post-translational modification may be responsible for this discrepancy. Changes at the mRNA level may not indicate changes at the protein level [56]. For fructose-bisphosphate aldolase, many modifications, such as phosphorylation [57], glycosylation (in fact, the fructose bisphosphate aldolase has putative glycosylation sites in its peptides) [58], acetylation [59] and protein fragmentation, etc.

The label-free analysis identified three cell deathrelated proteins $(2,26,29)$ involved in cell-cycle regulation, cell communication, or signal transduction. No 29 was identified as poly (ADP-ribose) polymerase (PARP) 4, PARP is a family of proteins involved in cellular processes mainly involving DNA repair and programmed cell death (apoptosis). No 2 was identified as CaM kinase II (CaMKII) alpha. Caspase 9 (a marker of mitochondrial-triggered apoptosis) was significantly reduced in the CaMKII inhibitor (CaMKIIN) transgenic hearts after ischemia reperfusion (I/R) injury [60]. No 26 was identified as prohibitin-2 (PHB2). PHB2, a potential tumor suppressor protein, plays important roles in inhibition of cell cycle progression, transcriptional regulation, apoptosis and the mitochondrial respiratory chain [61]. Morphological changes during development are often dependent on apoptosis [62]. Apoptosis plays a crucial role in organ formation, such as the formation of digits in vertebrates [63]. Cell death is usually accompanied by the elimination of abnormal cells or cells that fail to activate the normal embryonic genome transcriptome [63]. The morphology of the embryo changes significantly from the early trochophore larval stage to the late veliger larval stage, providing support for this idea.

In the label-free analysis, most proteins involved in cell division, cell shape, and differentiation were upregulated in veliger larvae. Src family kinases have been implicated in many biological processes such as cell adhesion, migration, proliferation and survival. Protein 13 was identified as a Src tyrosine kinase 1, which was upregulated 19.05 fold in the veliger stage. Src family 
tyrosine kinases (SFKs) play critical roles in many cell functions by coupling with upstream receptors and celladhesion signaling components. SFKs can be activated by integrin and other adhesion receptors, receptor tyrosine kinases, cytokine receptors, G-protein coupled receptors, and immune response receptors [64].

By 2-DE analysis, protein spot 70 was identified as COP9 signalosome subunit 4, isoform 3. It was upregulated in trochophore larvae (abundance was 3.20 in trochophore larvae and 1.41 in veliger larvae). The COP9 signalosome is a conserved protein complex that functions in the ubiquitin proteasome pathway. Freilich et al. [65] showed that the COP9 signalosome is conserved in invertebrates and has an essential role in animal development. Using label-free analysis, protein number 82 was identified as COP9 signalosome subunit 4 , which was also down-regulated in veliger larvae. As the trochophore stage is a key intermediate phase between embryonic and post embryonic development, the COP9 signalosome may be important in ubiquitinmediated protein degradation.

\section{Conclusion}

This study provides the first comparative analysis of proteomic profiles at different embryonic development stages of $H$. diversicolor. The results suggest that the combined use of 2-DE and label-free quantitative proteomics provides comprehensive proteome profiling, resulting in significant characterization and extensive comparison of the different embryonic development stages of $H$. diversicolor. We documented protein profiles in abalone development related to shell formation and differentiation in the larval retractor muscle, foot mass, and mantle.

\section{Additional files}

Additional file 1: Table S1. Primer sequences for realtime PCR assay. (DOC $31 \mathrm{~kb}$ )

Additional file 2: Table S2. Protein identification using MASCOT database searches. (DOC $238 \mathrm{~kb}$ )

Additional file 3: Table S3. Differentially abundances 2-DE gel protein spots between trochophore larvae and veliger larvae stage identified by MALDI-TOF-TOF. (DOC $128 \mathrm{~kb}$ )

Additional file 4: Table S4. Differentially abundances proteins between trochophore larvae and veliger larvae stage identified by label-free analysis. (DOC $220 \mathrm{~kb}$ )

\section{Abbreviations}

2-DE: two dimensional electrophoresis; ACN: acetonitrile; FDR: false discovery rate; GO: Gene Ontology; IEF: isoelectric focusing; IPG: immobilized pH gradient; MALDI: Matrix-assisted laser desorption/ionization; MALDI-TOF / TOF: MALDI / time-of-flight / time-of-flight; MS/ MS: tandem mass spectrometry; S/N: signal-to-noise; TFA: trifluoroacetic acid

\section{Acknowledgements}

We are grateful to Professor Dazhi Wang for his help with proteomic techniques. We thank LetPub (www.letpub.com) for its linguistic assistance during the preparation of this manuscript.

\section{Funding}

This work was financially supported by grants from NSFC (No. 31472277 , U1205121, 31640085), The Earmarked Fund for Modern Agro-industry Technology Research System (No. CARS-48), Henan Basic and f Advanced Research Program (No. 152300410206), Henan Science and Technology Program (No. 14B240003), the PhD Start-up Fund of Henan Normal University (No.qd13053), the Innovative Research Team (in Science and Technology) in University of Henan Province (15IRTSTHN018), Innovation Scientists and Technicians Troop Construction Projects of Henan Province (CXTD2016043), the Open Fund of Key Laboratory of Marine Environmental Corrosion and Biofouling, Institute of Oceanology, Chinese Academy of Sciences under MCKF201608, National Marine Economic Development Demonstration Project in Xiamen under Grant 16CZB023SF12, EUR-cooperative Foundation of Fujian Collaborative Innovation Center for Exploitation and Utilization of Marine Biological Resources under Grant FJMBIO1504. The Funding "31472277" "U1205121" "CARS-48" supported materials cultivation and collection consumption, while "31640085" "152300410206" "14B240003" "qd13053" "15IRTSTHN018" "CXTD2016043" supported experimental consumption, "MCKF201608" "16CZB023SF12" "FJMBIO1504" supported qRT-PCR experimental consumption. The funding bodies were not involved in the design of the study and collection, analysis, and interpretation of data and in writing the manuscript.

\section{Availability of data and materials}

All data generated or analysed during this study are included in this published article and its Additional files.

\section{Authors' contributions}

WY, CK and GD conceived the study, participated in its design and coordination and drafted the manuscript. GD, YZ and YG performed the experiments and wrote the paper. $\mathrm{XM}$ advised and analyzed the data. $\mathrm{MH}$ and JZ contributed reagents and materials (cultivation and fertilization of adult abalone materials, collected larval materials, performed samples and reagents preparation). XK reviewed and edited the manuscript. All authors read and approved the manuscript.

\section{Ethics approval}

Adult $H$. diversicolor were obtained from Dongshan Haitian Aquaculture in Fujian Province, China.The animal experiments were carried out in accordance with the protocols of the 'Guidelines for Experimental Animals' of the Ministry of Science and Technology (Beijing, China) and was approved by Animal Care and Use Ethics Committee of the Xiamen University.

Consent for publication

Not applicable

Competing interests

The authors declare that they have no competing interests.

\section{Publisher's Note}

Springer Nature remains neutral with regard to jurisdictional claims in published maps and institutional affiliations.

\section{Author details}

${ }^{1}$ College of Fisheries, Henan Normal University, Xinxiang 453007, China. ${ }^{2}$ State Key Laboratory of Marine Environmental Science, Fujian Collaborative Innovation Center for Exploitation and Utilization of Marine Biological Resources, Xiamen University, Xiamen, Fujian Province 361005, People's Republic of China. ${ }^{3}$ College of Life Sciences, Liaocheng University, Liaocheng 252059, China. 
Received: 21 July 2016 Accepted: 8 October 2017

Published online: 23 October 2017

\section{References}

1. Jackson DJ, Degnan SM, Degnan BM. Variation in rates of early development in Haliotis asinina generate competent larvae of different ages. Front Zool. 2012;9:2. 10.1186/1742-9994-9-2.

2. Gaume B, Fouchereau-Peron M, Badou A, Helléouet MN, Huchette S, Auzoux-Bordenave S. Biomineralization markers during early shell formation in the European abalone Haliotis tuberculata, Linnaeus. Mar Biol. 2011;158(2):341-53.

3. Gaume B, Denis F, Wormhoud AV, Huchette S, Jackson DJ, Avignon S, et al. Characterisation and expression of the biomineralising gene Lustrin $A$ during shell formation of the European abalone Haliotis tuberculata. Comp. Biochem Phys B. 2014;169(3):1-8.

4. USEPA. Methods for measuring the acute toxicity of effluents and receiving waters to freshwater and marine organisms, 5th Edition, EPA-821-R-02-012, 2002.

5. Ruppert EE, Fox RS, Barnes RB. Invertebrate zoology: a functional evolutionary approach. 7th ed. Belmont: Brooks Cole Thomson; 2004.

6. Liu H, Liu S, Ge Y, Liu J, Wang XY, Xie LP. Identification and characterization of a biomineralization related gene PFMG1highly expressed in the mantle of Pinctada fucata. Biochemistry. 2007:46:844-51.

7. An HS, Lee JW, Kim HC, Myeong Jl. Genetic characterization of five hatchery populations of the pacific abalone (Haliotis discus hannai) using microsatellite markers. Int J Mol Sci. 2011;12(8):4836-49.

8. Gwo JC, Chen CW, Cheng HY. Semen cryopreservation of small abalone (Haliotis diversicolor supertexa). Theriogenology. 2002;58(8):1563-78.

9. Di G, Kong X, Zhu G, Liu S, Zhang C, Ke C. Pathology and physiology of haliotis diversicolor with withering syndrome. Aquaculture. 2016:453:1-9.

10. Jardillier E, Rousseau M, Gendron-Badou A, Fröhlich F, Smith DC, Martin M, et al. A morphological and structural study of the larval shell from the abalone haliotis tuberculata. Mar Biol. 2008:154(4):735-44.

11. Auzoux-Bordenave S, Badou A, Gaume B, Berland S, Helléouet MN, Milet C, et al. Ultrastructure, chemistry andmineralogy of the growing shell of the European abalone Haliotis tuberculata. J Struct Biol. 2010;171:277-90.

12. Fiedler TJ, Hudder A, Mckay SJ, Shivkumar S, Capo TR, Schmale MC, et al. The transcriptome of the early life history stages of the California Sea hare Aplysia californica. Comp Biochem Physiol Part D Genomics Proteomics. 2010;5(2):165-70.

13. Huan P, Wang H, Dong B, Liu B. Identification of differentially expressed proteins involved in the early larval development of the Pacific oyster Crassostrea gigas. J Proteome. 2012;75(13):3855-65.

14. Lopez JL. Role of proteomics in taxonomy: the Mytilus Complex as a model of study. J Chromatogr B. 2005;815:261-74.

15. Gong L, Puri M, Ünlü M, Young M, Robertson $K$, Viswanathan $S$, et al. Drosophila ventral furrow morphogenesis: a proteomic analysis. Development. 2004;131:643-56.

16. Wang W, Meng B, Chen W, Ge X, Liu S, Yu J. A proteomic study on post diapaused embryonic development of brine shrimp (Artemia franciscana). Proteomics. 2007;7:3580-91.

17. Li J, Zhang L, Feng M, Zhang Z, Pan Y. Identification of the proteome composition occurring during the course of embryonic development of bees (Apis mellifera). Insect Mol Biol. 2009;18:1-9.

18. Thiyagarajan V, Qian PY. Proteomic analysis of larvae during development, attachment, and metamorphosis in the fouling barnacle, Balanus amphitrite. Proteomics. 2008:8:3164-72.

19. Thiyagarajan V, Wong T, Qian PY. 2D gel-based proteome and phosphoproteome analysis during larval metamorphosis in two major marine biofouling invertebrates. J Proteome Res. 2009:8:2708-19.

20. Mok FS, Thiyagarajan V, Qian PY. Proteomic analysis during larval development and metamorphosis of the spionid polychaete Pseudopolydora vexillosa. Proteome Sci. 2009;7:44.

21. Nomura M, Nakajima A, Inaba K. Proteomic profiles of embryonic development in the ascidian Ciona intestinalis. Develop Biol. 2009;325:46881.

22. Sun J, Zhang Y, Thiyagarajan V, Qian P, Qiu JW. Protein expression during the embryonic development of a gastropod. Proteomics. 2010;14:2701-11.

23. Lagarrigue M, Lavigne R, Guével B, Com E, Chaurand P, Pineau C. Matrixassisted laser desorption/ionization imaging mass spectrometry: a promising technique for reproductive research. Biol Reprod. 2012;86(3):74.

24. Zhu W, Smith JW, Huang CM. Mass spectrometry-based label-free quantitative proteomics. J Biomed Biotechnol. 2010;2010(1):840518.
25. Di G, You W, Yu J, Wang D, Ke C. Genetic changes in muscle protein following hybridization between Haliotis diversicolor reeve Japan and Taiwan populations revealed using a proteomic approach. Proteomics. 2013; 13(5):845-59.

26. Di G, Luo X, Huang M, Chen J, Kong X, Miao X, Ke C. Proteomic profiling of eggs from a hybrid abalone and its parental lines: Haliotis discus hannai Ino and Haliotis gigantea. Anim Genet. 2015;46(6):646-54

27. Dudoit S, Shaffer JP, Boldrick JC. Multiple hypotheses testing in microarray experiments. Stat Sci. 2003;18:71-103.

28. Kall L, Storey JD, MacCoss MJ, Noble WS. Posterior error probabilities and false discovery rates: two sides of the same coin. J Proteome Res. 2008;7(1):40-4.

29. Sun J, Zhang Y, Thiyagarajan V, Qian PY, Qiu JW. Protein expression during the embryonic development of a gastropod. Proteomics. 2010;10(14):2701-11.

30. Desjardins $P$, Hansen JB, Allen M. Microvolume protein concentration determination using the NanoDrop 2000c spectrophotometer. J Vis Exp. 2009;33(33):e1610

31. Yu Q, Xiong Y, Gao H, Liu J, Chen Z, Wang Q, et al. Comparative proteomics analysis of Spodoptera frugiperda cells during Autographa californica multiple nucleopolyhedrovirus infection. Virol J. 2015;12(1):115.

32. Nagatsu T, Levitt M, Udenfriend S. Tyrosine hydroxylase. The initial step in norepinephrine biosynthesis. J Biol Chem. 1964;239:2910-7.

33. Jéquier $E$, Lovenberg W, Sjoerdsma A. Tryptophan hydroxylase inhibition: the mechanism by which $\mathrm{p}$-chlorophenylalanine depletes rat brain serotonin. Mol Pharmacol. 1967:3:274-8.

34. Kretsinger RH, Uversky VN, Permyakov EA. Metal-Dependent Hydrolase. In: Kretsinger RH, Uversky VN, Permyakov EA,editors.Encyclopedia of Metalloproteins. New York:Springer; 2013. p.1378-1378.

35. Hernick M, Fierke C. Mechanisms of metal-dependent Hydrolases in metabolism. In: Mander L, H.W. Liu HW, editors. Comprehensive Natural Products II Chemistry and Biology. Netherlands: Elseiver; 2010. p.547-581.

36. Han B, Zhang L, Feng M, Fang Y, Li J. An integrated proteomics reveals pathological mechanism of honeybee (Apis cerena) sacbrood disease. J Proteome Res. 2013;12(4):1881-97.

37. Jackson DJ, Wörheide G, Degnan BM. Dynamic expression of ancient and novel molluscan shell genes during ecological transitions. BMC Evol Biol. 2007;7:1-17.

38. Fan W, Hu Y, Li C, Xie L, Zhang R. Cloning, characterization, and expression analysis of calreticulin from pearl oyster Pinctada fucata. Tsinghua Sci Technol. 2008;13:466-73.

39. Pernille R. Quality control in an unreliable world. EMBO J. 2008;27:303-5.

40. Baxter G, Morse DE. G protein and diacylglycerol regulate metamorphosis of planktonic molluscan larvae. Proc Natl Acad Sci U S A. 1987;84:1867-70.

41. Bunney TD, De Boer AH, Levin M. Fusicoccin signaling reveals 14-3-3 protein function as a novel step in left-right patterning during amphibian embryogenesis. Development. 2003;130:4847-58.

42. Toyo-oka K, Wachi T, Hunt RF, Baraban SC, Taya S, Ramshaw H, et al. 14-3-3e and $\zeta$ regulate neurogenesis and differentiation of neuronal progenitor cells in the developing brain. J Neurosci. 2014;34(36):12168-81.

43. Yamauchi T, Fujisawa $\mathrm{H}$. Tyrosine 3-monooxygenase is phosphorylated by Ca2+-, calmodulin-dependent protein kinase, followed by activation by activator protein. Biochem Biophys Res Commun. 1981;100:807-13.

44. Ichimura T, Isobe T, Okuyama T, Yamauchi T, Fujisawa H. Brain 14-3-3 protein is an activator protein that activates tryptophan 5-monooxygenase and tyrosine 3-monooxygenase in the presence of $\mathrm{Ca} 2+$, calmodulindependent protein kinase II. FEBS Lett. 1987;219:79-82.

45. Rizhova L, Klementiev B, Cambon K, Venero C, Sandi C, Vershinina E, et al. Effects of p2, a peptide derived from a homophilic binding site in the neural cell adhesion molecule on learning and memory in rats. Neuroscience. 2007;149(4):931-42.

46. Tang $X$, Zhou B. Ferritin is the key to dietary iron absorption and tissue iron detoxification in Drosophila melanogaster. FASEB J. 2013;27(1):288-98.

47. Tennessen JM, Bertagnolli NM, Evans J, Sieber MH, Cox J, Thummel CS. Coordinated metabolic transitions during drosophila embryogenesis and the onset of aerobic glycolysis. G3 (Bethesda Md). 2014;4(5):839-50.

48. Zhang $Y$, Meng $Q X$, Jiang $T M$, Wang $H Z$, Xie LP, Zhang RQ. A. Novel ferritin subunit involved in shell formation from the pearl oyster (Pinctada fucata). CompBiochem. Physiol B-Biochem Mol Biol. 2003;135:43-54.

49. Evans CCE, Dickinson AJG, Croll RP. Major muscle systems in the larval caenogastropod, ilyanassa obsoleta, display different patterns of development. J Morphol. 2009;270(10):1219-31.

50. Wollesen T, Wanninger A, Klussmann-Kolb A. Myogenesis in Aplysia californica (Cooper, 1863) (Mollusca, Gastropoda, Opisthobranchia) with 
special focus on muscular remodeling during metamorphosis. J Morphol. 2008;269(7):776-89.

51. Brock AR, Wang Y, Berger S, Renkawitzpohl R, Han VC, Wu Y, et al. Transcriptional regulation of profilin during wound closure in drosophila larvae. J Cell Sci. 2012;125(23):5667-76.

52. Argiriou A. Characterization of PROFILIN genes from allotetraploid (Gossypium hirsutum) cotton and its diploid progenitors and expression analysis in cotton genotypes differing in fiber characteristics. Mol Biol Rep. 2012;39(4):3523-32.

53. Kovar DR, Harris ES, Mahaffy R, Higgs HN, Pollard TD. Control of the assembly of ATP- and ADP-actin by formins and profilin. Cell. 2006;124:423-35.

54. Liu R, Jin JP. Calponin isoforms CNN1, CNN2 and CNN3: regulators for actin cytoskeleton functions in smooth muscle and non-muscle cells. Gene. 2016; 585(1):143-53

55. Heras H, Garin CF, Pollero RJ. Biochemical composition and energy sources during embryo development and in early juveniles of the snail Pomacea canaliculata (Mollusca: Gastropoda). J Exp Zool. 1998;280:375-83.

56. Guo B, Chen Y, Zhang G, Xing J, Hu Z, Feng W, et al. Comparative proteomic analysis of embryos between a maize hybrid and its parental lines during early stages of seed germination. PLoS One. 2013;8(6):e65867.

57. Clayton CE, Fox JA. Phosphorylation of fructose bisphosphate aldolase in Trypanosoma brucei. Mol Biochem Parasit. 1989;33(1):73-9.

58. Kamada M, Higashitani A, Ishioka N. Proteomic analysis of Arabidopsis root gravitropism. Biol Sci Space. 2005;19(19):148-54.

59. Pugh EL, Horecker BL. The effect of acetylation on the activity of rabbit muscle fructose diphosphate aldolase. Biochem Biophys Res Commun. 1967;26(3):360-5.

60. Joiner ML, Koval OM, Li J, He BJ, Allamargot C, Gao Z, et al. CaMKII determines mitochondrial stress responses in heart. Nature. 2012;491 (7423):269-73.

61. Gu MM, Kong JR, Di-Huang PT, Xie CY, Yang KY, et al. Molecular characterization and function of the prohibitin2 gene in Litopenaeus vannamei, responses to vibrio alginolyticus. Dev Comp Immunol. 2017;67:177-88,

62. Häcker G. The morphology of apoptosis. Cell Tissue Res. 2000;301:5-17.

63. Jacobson MD, Weil M, Raff MC. Programmed cell death review in animal development. Cell. 1997;88:347-54.

64. Parsons JT, Parsons SJ. Src family protein tyrosine kinases: cooperating with growth factor and adhesion signaling pathways. Curr Opin Cell Biol. 1997;9: 187-92.

65. Freilich S, Oron E, Kapp YA, Nevo-Caspi Y, Orgad S, Segal D, et al. The COP9 signalosome is essential for development of Drosophila melanogaster. Curr Biol. 1999;9(20):1187-90.

\section{Submit your next manuscript to BioMed Central and we will help you at every step:}

- We accept pre-submission inquiries

- Our selector tool helps you to find the most relevant journal

- We provide round the clock customer support

- Convenient online submission

- Thorough peer review

- Inclusion in PubMed and all major indexing services

- Maximum visibility for your research

Submit your manuscript at www.biomedcentral.com/submit

C) Biomed Central 